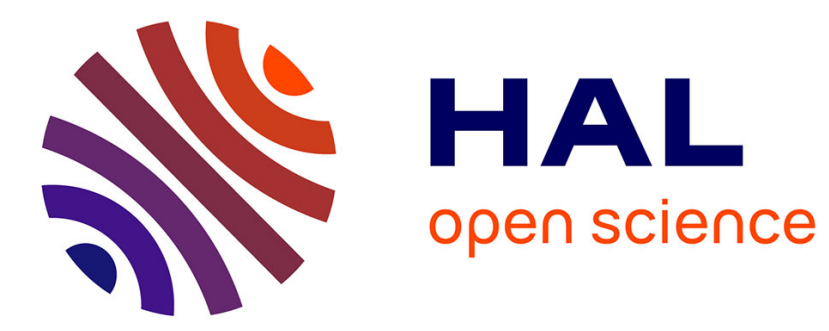

\title{
Bcl-2 can promote p53-dependent senescence versus apoptosis without affecting the G1/S transition
}

Vincent Rincheval, Flore Renaud, Christophe Lemaire, Nelly Godefroy, Pascale Trotot, Viviane Boulo, Bernard Mignotte, Jean-Luc Vayssière

\section{- To cite this version:}

Vincent Rincheval, Flore Renaud, Christophe Lemaire, Nelly Godefroy, Pascale Trotot, et al.. Bcl-2 can promote p53-dependent senescence versus apoptosis without affecting the G1/S transition. Biochemical and Biophysical Research Communications, 2002. hal-03002751

\section{HAL Id: hal-03002751 \\ https://hal.science/hal-03002751}

Submitted on 18 Dec 2020

HAL is a multi-disciplinary open access archive for the deposit and dissemination of scientific research documents, whether they are published or not. The documents may come from teaching and research institutions in France or abroad, or from public or private research centers.
L'archive ouverte pluridisciplinaire $\mathbf{H A L}$, est destinée au dépôt et à la diffusion de documents scientifiques de niveau recherche, publiés ou non, émanant des établissements d'enseignement et de recherche français ou étrangers, des laboratoires publics ou privés. 


\section{Bcl-2 can Promote p53-Dependent Senescence versus Apoptosis without Affecting the G1/S Transition}

Vincent Rincheval a, Flore Renaud ${ }^{\mathrm{b}}$, Christophe Lemaire ${ }^{\mathrm{a}}$, Nelly Godefroy ${ }^{\mathrm{a}}$, Pascale Trotot

${ }^{a}$, Viviane Boulo ${ }^{c}$, Bernard Mignotte ${ }^{\mathrm{a}, \mathrm{b}}$ and Jean-Luc Vayssière ${ }^{\mathrm{b}, *}$

${ }^{a}$ Université de Versailles / St Quentin-en-Yvelines, UPRESA-CNRS 8087, Laboratoire de génétique et biologie cellulaire, 45 avenue des Etats-Unis, 78035 Versailles cedex, France.

${ }^{\mathrm{b}}$ Ecole Pratique des Hautes Etudes, Laboratoire de génétique moléculaire et physiologique, 45 avenue des Etats-Unis, 78035 Versailles cedex, France.

c Institut Gustave Roussy, CNRS UMR 1599, Unité de génétique oncologique, 94805 Villejuif cedex, France.

* To whom correspondence and reprint requests should be addressed. Fax: (33) 139253655. E-mail: vayssiere@genetique.uvsq.fr.

Footnote: Viviane Boulo present address is Universite de Montpellier II, IFREMER / CNRS UM2, Défense et résistance chez les invertébrés marins, 34095 Montpellier, France. 
With the aim to identify events involved in the determination of p53-dependent apoptosis versus growth arrest, we used rat embryo fibroblasts expressing a temperature-sensitive mutant (tsA58) of the SV40 large tumour antigen (LT). Heatinactivation of LT leads to p53 activation and commitment to a senescent-like state (REtsA15 cell line) or apoptosis (REtsAF cell line). We report that senescence is associated with high levels of the anti-apoptotic Bcl-2 protein and a cell cycle arrest in G1 phase, whereas apoptosis is associated with low levels of Bcl-2 and a cell cycle arrest in G2 phase. Here we show that Bcl-2, which can inhibit apoptosis and proliferation, turns the apoptotic phenotype into a senescent-like phenotype in G2 phase. This result suggests that Bcl-2-dependent inhibition of apoptosis could be crucial for the commitment to replicative senescence, whereas its ability to inhibit G1 progression would not be required.

Key Words: bcl-2; senescence; apoptosis; cell cycle. 
Normal cells in culture exhibit a limited mitotic life-span [1]. After a finite number of divisions, cells stop to proliferate and cannot be induced to enter $\mathrm{S}$ phase or to divide. This process is known as replicative or cellular senescence. The use of DNA tumour viruses has been particularly important to identify effectors of replicative senescence. For instance, it has been shown that inhibition of the $\mathrm{Rb}$ and p53 proteins by the large $\mathrm{T}$ antigen of the SV40 virus (LT) is crucial to bypass replicative senescence and to trigger the rodent cells to proliferate indefinitely [2,3]. When hypophosphorylated, the $\mathrm{Rb}$ protein blocks cell proliferation in G1 phase [4]. This process becomes irreversible in senescent cells which ordinary fail to phosphorylate $\mathrm{Rb}$ [5]. The p53 protein would also be critical for replicative senescence at least because of its participation to $\mathrm{Rb}$ activation. Indeed, p53 up-regulates transcription of the $p 21^{\text {waf-1/cipl/sdil }}$ gene which encodes a cdki that inhibits Rb phosphorylation [6]. In addition to its anti-proliferative effect, p53 can induce an intrinsic cell death program, termed apoptosis. p53 essentially triggers apoptosis in stress conditions, notably via the expression of several target genes which promote cell death [7]. For instance, p53 induces expression of bax which facilitates the release of pro-apoptotic factors from the mitochondria [8]. Bax belongs to the Bcl-2 family, which contains positive and negative regulators of apoptosis. Contrary to Bax, the Bcl-2 protein prevents cells from undergoing apoptosis induced by various stimuli in a wide variety of cell types [9]. It has been suggested that a balance between expression of these pro- and anti-apoptotic homologues could determine the choice between cell survival and apoptosis [10]. In this way, it was previously reported that Bcl-2 may be important for cell survival during senescence [11]. More recent studies have shown that Bcl-2 also inhibits cell cycle progression in G1 phase [12], but the mechanisms underlying this new function are poorly understood.

In order to identify the events involved in the determination of p53-dependent growth arrest versus apoptosis, we used rat embryo fibroblasts expressing a temperature-sensitive mutant (tsA58) of LT. This mutant cannot interact with p53 at restrictive temperature. Thus, the cells are immortalised at permissive temperature $\left(33^{\circ} \mathrm{C}\right)$, whereas heat-inactivation of LT leads to a loss of the immortalised state at restrictive temperature $\left(39.5^{\circ} \mathrm{C}\right)$ [13]. We have isolated several cell lines which harbour distinct phenotypes at $39.5^{\circ} \mathrm{C}$. Some of them exhibit a senescent-like phenotype, whereas others exhibit an apoptotic phenotype [14]. Here, we have analysed two model cell lines undergoing pseudo-senescence (REtsA15 cells) or apoptosis (REtsAF cells) at $39.5^{\circ} \mathrm{C}$. We report that senescence of REtsA15 cells is associated with a cell cycle arrest in G1 phase as well as high levels of the anti-apoptotic Bcl-2 protein. Conversely, we show that apoptosis of REtsAF cells is associated with low levels of Bcl-2 and a cell cycle arrest in G2 phase. Since the overexpression of bcl-2 turns the apoptotic phenotype into a senescent-like phenotype in G2 phase, our results suggest that Bcl-2dependent inhibition of apoptosis could be crucial for the determination of replicative senescence, whereas its ability to inhibit cell cycle progression in G1 phase would be dispensable. 


\section{MATERIALS AND METHODS}

Cell lines and cell culture. Isolation of the REtsAF cell line has been described previously [13]. REtsA15 cell line was isolated at low cell density from a rat embryo fibroblast culture transfected with the tsA58 allele of the LT gene. REtsAF-Bcl-2 cell line is derived from REtsAF cells and overexpresses the human $b c l-2$ gene [15]. Cell culture was performed as previously described [15].

RT-PCR assay. RNA were isolated using the guanidium isothiocyanate method [16]. To estimate the level of bcl-2 and bax mRNA, RT-PCR was performed as previously described [17] using specific primers ( $b c l-2$ : forward primer 5'agcctgtgccacctgtggt 3', reverse primer 5'acgctttgccacggtggtg3'; bax: forward primer 5'ggagcagctcggaggcg3', reverse primer 5'ttcttggtggatgcatcctg3'). Amplified products, were collected in the exponential phase (bcl-2: 143 bp / 25-30 cycles and bax: 158 bp / 32-35 cycles), separated on 10\% acrylamide gels, transferred to hybond $\mathrm{N}+$ membranes (Amersham) and hybridised with ${ }^{32} \mathrm{P}$ labelled specific probes. Quantification for each PCR was done using ImageQuant software after scanning the autoradiograms.

Western-blot analysis. SDS-page and Western blot were performed as previously described [15]. The following antibodies were used in this study: anti-Bax (N-19, Santa Cruz), anti-Bcl-2 (83-8B, MBL), anti-Rb (G3-245, Pharmingen) and anti-Waf-1 (C-19, Santa Cruz).

Flow cytometry. Flow cytometry measurements were performed with a XL3C flow cytometer (Beckman-Coulter France). For cell viability, cells were incubated with $0.2 \mu \mathrm{g} / \mathrm{ml}$ fluorescein diacetate (FDA) $30 \mathrm{~min}$ and $5 \mu \mathrm{g} / \mathrm{ml}$ propidium iodide (PI) $5 \mathrm{~min}$ prior analysis. FDA (Polysciences) is a nonfluorescent compound which becomes fluorescent (free fluorescein) when cleaved by esterases in living cells. PI (sigma) specifically penetrates in necrotic cells, after loss of their plasma membrane integrity. For cell cycle analysis, cells were fixed with ethanol $70 \%$ at $-20^{\circ} \mathrm{C}$, rinsed with PBS and incubated with PI $100 \mu \mathrm{g} / \mathrm{ml}$ and RNAse (Roche) $0.25 \mathrm{mg} / \mathrm{ml}$ in PBS $15 \mathrm{~min}$. Cell debris (including Sub-G1 cells) were excluded from cell cycle analysis. For measurement of BrdU incorporation, cells were incubated for $30 \mathrm{~min}$ with $30 \mu \mathrm{M}$ BrdU (Sigma), fixed with ethanol $70 \%$ at $-20^{\circ} \mathrm{C}$ and rinsed with PBS. Next, cells were incubated in $\mathrm{HCl} 2 \mathrm{~N} 20 \mathrm{~min}$ at $37^{\circ} \mathrm{C}$, rinsed with PBS, incubated with $0.5 \%$ tween $20,0.5 \%$ NGS and $4 \%$ (v/v) of a rat anti-BrdU antibody (Sera-Lab) $1 \mathrm{~h}$, rinsed with PBS and incubated 30 min with $0.5 \%$ tween 20, 0.5\% NGS (Dako) and 4\% (v/v) of a FITC-conjugated anti-rat secondary antibody (Jackson). Finally, cells were rinsed in PBS and the percentage of BrdU (FITC) positive cells was determined. 


\section{RESULTS}

A Loss of the Immortalised State Leads to Distinct Phenotypes in REtsA15 and REtsAF Cells

At permissive temperature $\left(33^{\circ} \mathrm{C}\right)$, REtsA15 and REtsAF fibroblasts proliferate indefinitely. It was previously shown that heat inactivation of LT induces replicative senescence when cells have bypassed their normal proliferative potential [18]. Figure 1a shows that REtsA15 cells progressively stop to proliferate at restrictive temperature $\left(39.5^{\circ} \mathrm{C}\right.$, left panel) and adopt an enlarged morphology (right panel), which is characteristic of cellular senescence in vitro. On the contrary, the number of REtsAF cells progressively decreases at $39.5^{\circ} \mathrm{C}$ and a photograph clearly shows that they are condensed and detached from their culture dish. A condensation and a loss of cell adhesion are morphological features of the programmed cell death, termed apoptosis. It was previously shown that the REtsAF cells are positive for TUNEL, a technique that reveals DNA fragmentation of apoptotic or necrotic cells [14]. In order to further characterise the phenotype of REtsAF cells at $39.5^{\circ} \mathrm{C}$, we have used the FDA/PI staining method (see materials and methods) which permits to separate living cells from apoptotic or necrotic cells [19]. Living cells are FDA positive whereas FDA negative-dead cells can be divided into two populations: PI positive-necrotic cells and PI negative-apoptotic cells. Figure $1 \mathrm{~b}$ shows that after $48 \mathrm{~h}$ at $39.5^{\circ} \mathrm{C}$, most of REtsAF cells are apoptotic whereas REtsA15 cells remain essentially alive. These results show that a loss of immortalisation can lead to a senescent-like state or to an apoptotic cell death, depending on the cell line.

\section{bcl-2 is Differentially Expressed in REtsA15 and REtsAF Cells}

When activated in pathological conditions, p53 can regulate positively or negatively the expression of several genes from the $b c l-2$ family. For instance, p53 stimulates the expression of the pro-apoptotic bax gene and conversely inhibits the expression of the antiapoptotic $b c l-2$ gene [20]. In order to determine if the ratio between Bax and Bcl-2 is correlated to REtsAF and REtsA15 cell viability, we have studied their expression in both cell lines. The results presented in Figure 2 show that the basal expression of bax at $33^{\circ} \mathrm{C}$ is the same in REtsAF and REtsA 15 cells. At $39.5^{\circ} \mathrm{C}$, when p53 is activated, there is a stimulation of bax transcription. Even though this stimulation appears to be faster in REtsAF cells, the Bax protein levels increase similarly in both cell lines. On the contrary, Figure 2 shows that the expression of $b c l-2$ is strongly induced in REtsA15 cells at $39.5^{\circ} \mathrm{C}$, whereas it is not in REtsAF cells and that both mRNA and protein levels of $b c l-2$ are higher in REtsA15 cells at $33^{\circ} \mathrm{C}$ and $39.5^{\circ} \mathrm{C}$. Therefore, our results suggest that higher amounts of Bcl-2 could inhibit REtsA15 apoptosis and promote replicative senescence at $39.5^{\circ} \mathrm{C}$.

\section{REtsA15 and REtsAF Cells Harbour Distinct Regulations of Cell Cycle at $39.5^{\circ} \mathrm{C}$}

p53 has also the ability to up-regulate transcription of the $p 21^{\text {waf-1/cip } 1 / s d i 1}$ gene which encodes a cdki that inhibits G1/S transition [6]. A Western-blot analysis shows that the $\mathrm{p} 21^{\text {Waf-1/Sdi-1/Cip1 }}$ protein strongly accumulates in both REtsAF and REtsA15 cell lines at 
$39.5^{\circ} \mathrm{C}$ (Fig. 3). Even though the $\mathrm{p} 21^{\text {Waf-1/Sdi-1/Cip1 }}$ protein accumulation appears to be more rapid and intense in REtsA15 cells, this result clearly shows that p53 is actually activated in both cell lines at $39.5^{\circ} \mathrm{C}$. In order to examine the influence of $\mathrm{p} 21^{\text {Waf- } 1 / \mathrm{Sdi}-1 / \mathrm{Cip} 1}$ accumulation on $\mathrm{Rb}$ phosphorylation, we have also performed a Western-blot analysis of $\mathrm{Rb}$. Figure 3 shows that three forms of $\mathrm{Rb}$ which correspond to the hypophosphorylated ( 105 ), phosphorylated (p110) and hyperphosphorylated (p115) Rb, can be distinguished at $33^{\circ} \mathrm{C}$. Unexpectedly, the active p105 form of $\mathrm{Rb}$ seems to disappear rapidly in REtsAF cells at $39.5^{\circ} \mathrm{C}$ whereas it accumulates in REtsA15 cells, like p110/115. These results suggest that $\mathrm{Rb}$ activity at $39.5^{\circ} \mathrm{C}$ is different in REtsAF and REtsA15 cell lines and that a strong accumulation of $\mathrm{p} 21^{\text {Waf- } 1 / \mathrm{Sdi}-1 / \mathrm{Cip} 1}$ at $39.5^{\circ} \mathrm{C}$ is not sufficient to maintain hypophosphorylated $\mathrm{Rb}$ in REtsAF cells.

Next, we have performed a flow cytometric analysis at $33^{\circ} \mathrm{C}$ and $39.5^{\circ} \mathrm{C}$ to examine the effect of $\mathrm{Rb}$ phosphorylation on REtsA15 / REtsAF cell cycle regulation and DNA synthesis. We have first estimated the proportion of cells in $\mathrm{S}$ phase by measuring the incorporation of bromodeoxyuridine (BrdU). Figure 4a shows that the percentage of BrdU positive cells decreases at $39.5^{\circ} \mathrm{C}$ in both cell lines, suggesting that the REtsAF and REtsA15 cells both stop to proliferate. However, the inhibition of DNA synthesis is much more rapid in REtsA15 cells. Next, we have examined the distribution of REtsAF and REtsA15 cells in the different phases of cell cycle (Fig. 4b). This distribution is identical at $33^{\circ} \mathrm{C}$. However, when shifted at $39.5^{\circ} \mathrm{C}$, the REtsA15 cells essentially accumulate in $\mathrm{G} 1$ phase whereas REtsAF cells accumulate in $\mathrm{G} 2 / \mathrm{M}$ phases (actually in G2 phase since chromatin is not condensed (data not shown)). These results are in agreement with the status of $\mathrm{Rb}$ in these cells, suggesting that $\mathrm{Rb}$ is not inhibited by $\mathrm{LT}$ at $39.5^{\circ} \mathrm{C}$, like p53. They also raise the idea that cell survival could depend on cell cycle position at $39.5^{\circ} \mathrm{C}$ since a G1 block is associated with cell survival whereas a G2 block is associated with cell death. Finally, it is possible that the G2 arrest results from the expression of the 14-3-3- $\sigma$ and GADD45 genes, which are other targets of p53 [21,22].

Overexpression of bcl-2 in REtsAF Cells Turns the Apoptotic Phenotype into a Senescent-like Phenotype in G2 Phase

The results described above raise the possibility that the amount of Bcl-2 as well as cell cycle regulation could influence the choice between replicative senescence and apoptosis upon p53 activation, in REtsA15 / REtsAF cells. In addition to its anti-apoptotic role, Bcl-2 has also been described to inhibit cell cycle progression in G1 phase [12]. Thus, it was of particular interest to determine if $\mathrm{Bcl}-2$ was able to influence the phenotype observed at $39.5^{\circ} \mathrm{C}$, in a cell cycle-dependent or independent manner. In order to test these hypotheses, we have used the REtsAF-Bcl-2 cell line which overexpresses the human $b c l-2$ gene [15]. An FDA/PI analysis of REtsAF-Bcl-2 cells (Fig. 5a) clearly shows that Bcl-2 protects REtsAF cells from apoptosis at $39.5^{\circ} \mathrm{C}$. Indeed, after $48 \mathrm{~h}$ passed at restrictive temperature, there is $10 \%$ of cell death in REtsAF cells overexpressing bcl-2 versus $90 \%$ in REtsAF cells (Fig. 1b). Interestingly, a photograph of REtsAF-Bcl-2 cells shows that surviving cells adopt a senescent-like morphology (Fig. 5b). Thus, bcl-2 expression would not only inhibits apoptosis but would also allow cells to undergo senescence. Next, Figure $5 \mathrm{c}$ shows that the 
accumulation of Bax and $\mathrm{p} 21^{\text {Waf-1/Sdi-1/Cip1 }}$ is similar in REtsAF-Bcl-2 and REtsAF cells at $39.5^{\circ} \mathrm{C}$. It also shows that hypophosphorylated $\mathrm{Rb}(\mathrm{p} 105)$ rapidly disappears at $39.5^{\circ} \mathrm{C}$, like in REtsAF cells. Finally, Figure $5 \mathrm{~d}$ and $5 \mathrm{e}$ show that $b c l-2$ overexpression does not influence cell cycle regulation of REtsAF cells, since REtsAF-Bcl-2 cells still exhibit a delayed inhibition of DNA synthesis (versus REtsA15 cells) and accumulate in G2 phase. Thus, it appears that Bcl-2 could promote the determination of replicative senescence independently of the regulation of $\mathrm{G} 1 / \mathrm{S}$ transition in this system. It also suggests that a senescent-like phenotype can be established in G2 phase and that the Bcl-2-dependent inhibition of apoptosis can be essential for the determination of replicative senescence.

\section{DISCUSSION}

In this work, we point out that a loss of the immortalised state, involving p53 activation, can be associated with either a senescent-like state (REtsA15 cells) or apoptosis (REtsAF cells). The p53-induced senescent state, which is established within a few days, is probably different from classical replicative senescence obtained with primary cultured cells. For instance, we were unable to detect a SA- $\beta$-gal (senescence associated $\beta$-galactosidase) activity [23]. However, we and others have shown that this process exhibits important molecular and cellular features of replicative senescence, such as p21 Waf-1/Sdi-1/Cip1 accumulation, maintenance of hypophosphorylated $\mathrm{Rb}$, irreversibility of growth arrest in G1 phase and morphological changes [24].

In this article, we report that the Bcl-2 protein level is important in choosing between p53-induced senescence versus apoptosis at restrictive temperature. Indeed, our results clearly show that Bcl-2 inhibits apoptosis of REtsAF cells at $39.5^{\circ} \mathrm{C}$ and suggest that this inhibition allows the occurrence of replicative senescence, despite a growth arrest in G2 phase. The p53 protein can induce apoptosis via the induction of several target genes involved in the mitochondrial and the death receptor-induced apoptotic pathways. Several mediators of the p53-induced apoptotic response are pro-apoptotic members of the Bcl-2 family, such as Bax, Noxa and Puma which trigger cytochrome c release and activation of apoptosome [7]. Interestingly, we have previously shown that a shift of REtsAF cells at $39.5^{\circ} \mathrm{C}$ is associated with a decrease in mitochondrial membrane potential $(\Delta \Psi \mathrm{m})$ [25], and that this decrease is inhibited by Bcl-2 overexpression [26]. Thus it seems that Bcl-2 inhibits the p53-dependent mitochondrial apoptotic pathway. The $\mathrm{p} 53$ protein can also promote apoptosis via a repression of survival genes, such as $b c l-2$ and $I G F-1 R[27,28]$. Surprisingly, we found that p53 activation is correlated with an accumulation of Bcl-2 in REtsA15 cells. However, we have observed that in these cells, $b c l-2$ mRNA level decreases in the first hours passed at $39.5^{\circ} \mathrm{C}$ and then increases during several days (data not shown). Thus, p53 may have a dual effect on Bcl-2 level: a short time inhibitory effect and a long time stimulatory effect.

We also report that there is a correlation between cell cycle regulation and cell fate at $39.5^{\circ} \mathrm{C}$ : senescence is correlated with a rapid inhibition of DNA synthesis and a growth arrest in G1 phase (REtsA15), whereas apoptosis is correlated with a delayed inhibition of DNA synthesis and a block in G2 phase (REtsAF). The fact that REtsAF-Bcl-2 cells seem to senesce in $\mathrm{G} 2$ phase suggests that the inhibition of G1/S transition would be dispensable for 
the commitment to replicative senescence. It also indicates that Bcl-2 cannot promote a G1 block in these cells. This result could be related to the fact that Bcl-2-dependent inhibition of G1 progression was demonstrated with quiescent cells re-entering cell cycle [12], whereas REtsAF cells are cycling cells at $33^{\circ} \mathrm{C}$. Hypophosphorylated $\mathrm{Rb}$ triggers a growth arrest in $\mathrm{G} 1$ phase via the inhibition of E2F transcription factors, that are required for $\mathrm{S}$ phase entry and DNA synthesis [29]. Interestingly, it has been reported that the E2F-1 protein also reinforces the pro-apoptotic activity of p53 [30]. Thus, contrary to REtsA15, an inability of the REtsAF cells to stop to proliferate in G1 phase, which is correlated to an Rb hyperphosphorylation, could favour their own death through the activation of E2F-1. Therefore, it would be of particular interest to test the involvement of cell cycle regulation in apoptosis by determining if a G1 block imposed on REtsAF cells at $39.5^{\circ} \mathrm{C}$ (via a drug treatment or expression of an unphosphorylable $\mathrm{Rb}$ mutant) could result in a senescent phenotype. The fact that $\mathrm{Rb}$ is rapidly phosphorylated in REtsAF cells, despite high amounts of $\mathrm{p} 21^{\text {Waf-1/Sdi-1/Cip1 }}$, remains unexplained. However, it seems likely that this process could originate in a cyclin/cdk overactivation or a $\mathrm{p} 21^{\text {Waf-1/Sdi-1/Cip1 }}$ mutation.

Finally, it is noteworthy that $b c l-2$ can promote replicative senescence whereas it was first identified as an oncogene involved in a follicular lymphoma. This paradox could be related to the fact that both commitment to replicative senescence and oncogenesis would necessitate inhibition of apoptosis.

\section{ACKNOLEDGMENTS}

We thank Dr. Monique Guéride for her reading of the manuscript. We acknowledge Dr Jean Feunteun for his collaboration. This work was supported in part by grants from the Association pour la Recherche contre le Cancer (\#4480). We are grateful to the Conseil régional d'Ile-de-France, the Association pour la Recherche contre le Cancer, the Ligue Nationale Contre le Cancer, and the Fondation pour la Recherche Médicale which all contributed financial support towards equipment used in our laboratories.

\section{REFERENCES}

[1] L. Hayflick, The limited in vitro lifetime of human diploid cell strains, Exp. Cell. Res. 37 (1965) 614-636.

[2] J.A. DeCaprio, J.W. Ludlow, J. Figge, J.Y. Shew, C.M. Huang, W.H. Lee, E. Marsilio, E. Paucha, D.M. Livingston, SV40 large tumor antigen forms a specific complex with the product of the retinoblastoma susceptibility gene, Cell 54 (1988) 275-283.

[3] J.Y. Zhu, M. Abate, P.W. Rice, C.N. Cole, The ability of simian virus-40 large T antigen to immortalize primary mouse embryo fibroblasts cosegregates with its ability to bind to p53, J. Virol. 65 (1991) 6872-6880.

[4] D.W. Goodrich, N.P. Wang, Y.W. Qian, E.Y. Lee, W.H. Lee, The retinoblastoma gene product regulates progression through the G1 phase of the cell cycle, Cell 67 (1991) 293-302. 
[5] P.A. Futreal, J.C. Barrett, Failure of senescent cells to phosphorylate the RB protein, Oncogene 6 (1991) 1109-1113.

[6] J.W. Harper, G.R. Adami, N. Wei, K. Keyomarsi, S.J. Elledge, The p21 Cdk-interacting protein Cip1 is a potent inhibitor of G1 cyclin- dependent kinases, Cell 75 (1993) 805-816.

[7] K.M. Ryan, A.C. Phillips, K.H. Vousden, Regulation and function of the p53 tumor suppressor protein, Curr. Opin. Cell Biol. 13 (2001) 332-337.

[8] M. Narita, S. Shimizu, T. Ito, T. Chittenden, R.J. Lutz, H. Matsuda, Y. Tsujimoto, Bax interacts with the permeability transition pore to induce permeability transition and cytochrome c release in isolated mitochondria, Proc. Natl. Acad. Sci. USA 95 (1998) 1468114686.

[9] B. Mignotte, J.L. Vayssière, Mitochondria and apoptosis, Eur. J. Biochem. 252 (1998) 115.

[10] Z.N. Oltvai, C.L. Milliman, S.J. Korsmeyer, bcl-2 heterodimerizes in vivo with a conserved homolog, bax, that accelerates programmed cell death, Cell 74 (1993) 609-619.

[11] E. Wang, Senescent human fibroblasts resist programmed cell death, and failure to suppress bcl2 is involved, Cancer Res. 55 (1995) 2284-2292.

[12] G. Vairo, T.J. Soos, T.M. Upton, J. Zalvide, J. A. DeCaprio, M. E. Ewen, A. Koff, J. M. Adams, Bcl-2 retards cell cycle entry through p27(Kip1), pRB relative p130, and altered E2F regulation, Mol. Cell. Biol. 20 (2000) 4745-4753.

[13] C.A. Petit, M.Y. Gardes, J. Feunteun, Immortalization of rodent embryo fibroblast by SV40 is maintained by the A gene, Virology 127 (1983) 74-82.

[14] D.Q. Zheng, J.L. Vayssière, H. Lecoeur, P.X. Petit, A. Spatz, B. Mignotte, J. Feunteun, Apoptosis is antagonized by Large $\mathrm{T}$ antigens in the pathway to immortalization by polyomaviruses, Oncogene 9 (1994) 3345-3351.

[15] V. Rincheval, F. Renaud, C. Lemaire, B. Mignotte, J.L. Vayssière, Inhibition of Bcl-2dependent cell survival by a caspase inhibitor: a possible new pathway for Bcl-2 to regulate cell death, FEBS lett. 460 (1999) 203-206.

[16] J.M. Chirgwin, A.E. Przybyla, R.J. Mac Donald, W.J. Rutter, Isolation of biologically active ribonucleic acid from sources enriched in ribonuclease, Biochemistry 18 (1979) 52945299.

[17] F. Renaud, S. Desset, L. Oliver, G. Gimenez-Gallego, E. Van Obberghen, Y. Courtois, M. Laurent, The neurotrophic activity of fibroblast growth factor 1 (FGF1) depends on endogenous FGF1 expression and is independent of the mitogen-activated protein kinase cascade pathway, J. Biol. Chem. 271 (1996) 2801-2811.

[18] Z. Ikram, T. Norton, P.S. Jat, The biological clock that measures the mitotic life-span of mouse embryo fibroblasts continues to function in the presence of simian virus 40 large tumor antigen, Proc. Natl. Acad. Sci. USA 91 (1994) 6448-6452.

[19] D. Bartkowiak, S. Hogner, H. Baust, W. Nothdurft, E. M. Rottinger, Comparative analysis of apoptosis in HL60 detected by annexin-V and fluorescein-diacetate, Cytometry 37 (1999) 191-196.

[20] T. Miyashita, M. Harigai, M. Hanada, J.C. Reed, Identification of a p53-dependent negative response element in the bcl- 2 gene, Cancer Res. 54 (1994) 3131-3135. 
[21] H. Hermeking, C. Lengauer, K. Polyak, T.C. He, L. Zhang, S. Thiagalingam, K.W. Kinzler, B. Vogelstein, 14-3-3 sigma is a p53-regulated inhibitor of G2/M progression, Mol. Cell 1 (1997) 3-11.

[22] X.W. Wang, Q. Zhan, J.D. Coursen, M.A. Khan, H.U. Kontny, L. Yu, M.C. Hollander, P.M. O'Connor, A.J. Jr. Fornace, C.C. Harris, GADD45 induction of a G2/M cell cycle checkpoint, Proc. Natl. Acad. Sci. USA 96 (1999) 3706-3711.

[23] G.P. Dimri, X. Lee, G. Basile, M.Acosta, G. Scott, C. Roskelley, E.E. Medrano, M. Linskens, I. Rubelj, O. Pereira-Smith. et al. A biomarker that identifies senescent human cells in culture and in aging skin in vivo, Proc. Natl. Acad. Sci. USA 92 (1995) 9363-9367. [24] E.S. Gonos, J.S. Burns, G.R. Mazars, A. Kobrna, T.E. Riley, S.C. Barnett, G. Zafarana, R.L. Ludwig, Z. Ikram, A.J. Powell, P.S. Jat, Rat embryo fibroblasts immortalized with simian virus 40 large $\mathrm{T}$ antigen undergo senescence upon its inactivation, Mol. Cell. Biol. 16 (1996) 5127-5138.

[25] J.L. Vayssière, P.X. Petit, Y. Risler, B. Mignotte, Commitment to apoptosis is associated with changes in mitochondrial biogenesis and activity in cell lines conditionally immortalized with Simian Virus 40, Proc. Natl. Acad. Sci. USA 91 (1994) 11752-11756.

[26] I. Guénal, C. Sidoti-de Fraisse, S. Gaumer, B. Mignotte, Bcl-2 and Hsp27 act at different levels to suppress programmed cell death, Oncogene 15 (1997) 347-360.

[27] T. Miyashita, S. Krajewski, M. Krajewska, H.G. Wang, H.K. Lin, D. Liebermann, B. Hoffman, J.C. Reed, Tumor suppressor p53 is a regulator of Bcl-2 and bax gene expression in vitro and in vivo, Oncogene 9 (1994) 1799-1805.

[28] M. Neuberg, , L. Buckbinder, , B. Seizinger, N. Kley, The p53/IGF-1 receptor axis in the regulation of programmed cell death, Endocrine 7 (1997) 107-109.

[29] J.W. Harbour, D.C. Dean, The Rb/E2F pathway: expanding roles and emerging paradigms, Genes Dev. 14 (2000) 2393-2409.

[30] X.Q. Qin, D.M. Livingston, W.G. Jr Kaelin, P.D. Adams, Deregulated transcription factor E2F-1 expression leads to S-phase entry and p53-mediated apoptosis, Proc. Natl. Acad. Sci. USA 91 (1994) 10918-10922. 


\section{FIGURES}
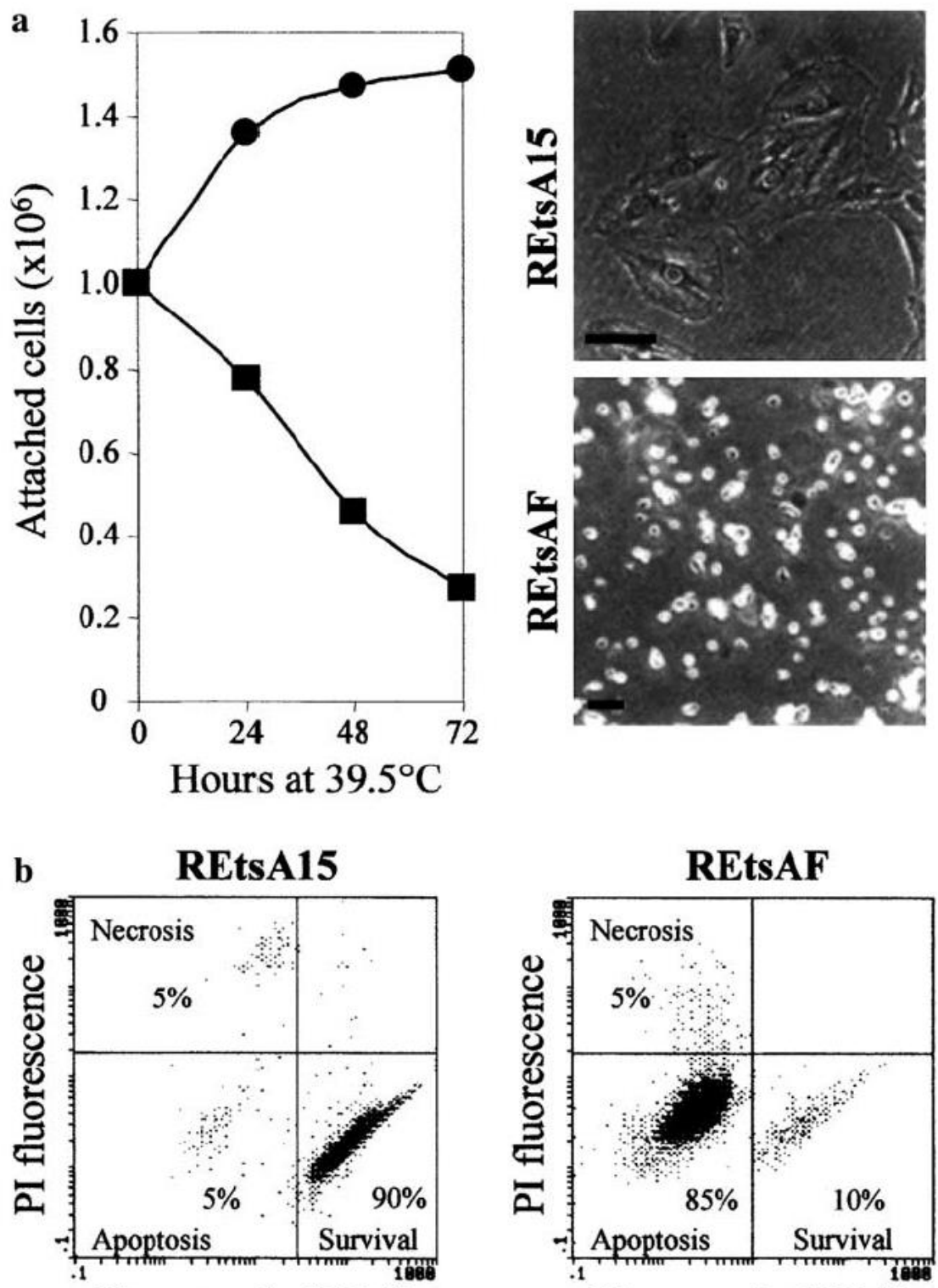

Fluorescein (FDA)

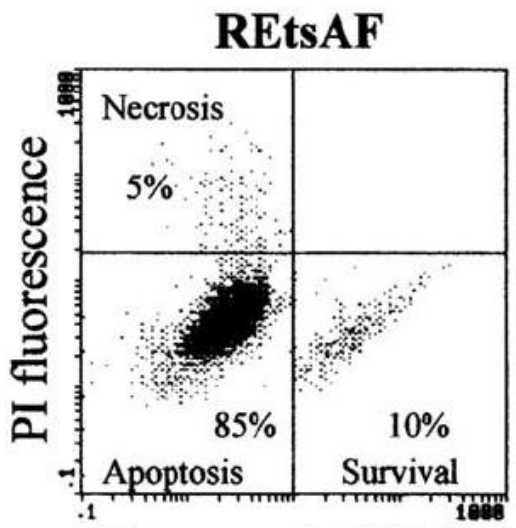

Fluorescein (FDA)

FIG. 1. Analysis of REtsA15 and REtsAF phenotype at $39.5^{\circ} \mathrm{C}$. (a) REtsA 15 and REtsAF cells were incubated at $39.5^{\circ} \mathrm{C}$. REtsA15 cells $(\bullet)$ progressively stop to proliferate and harbour a senescent-like morphology whereas REtsAF cells ( $\mathbf{n})$ are detached from the culture dish and harbour an apoptotic-like phenotype (photographs were taken $48 \mathrm{~h}$ after shift at $39.5^{\circ} \mathrm{C}$ ). (b) A flow cytometric analysis of cell death was performed on both cell lines after $48 \mathrm{~h}$ at $39.5^{\circ} \mathrm{C}$. The cytograms obtained with REtsA15 and REtsAF cells show three distinct populations of cells: surviving, apoptotic and necrotic cells. REtsAF cells undergo a massive apoptotic cell death while most of REtsA15 cells remain alive. 

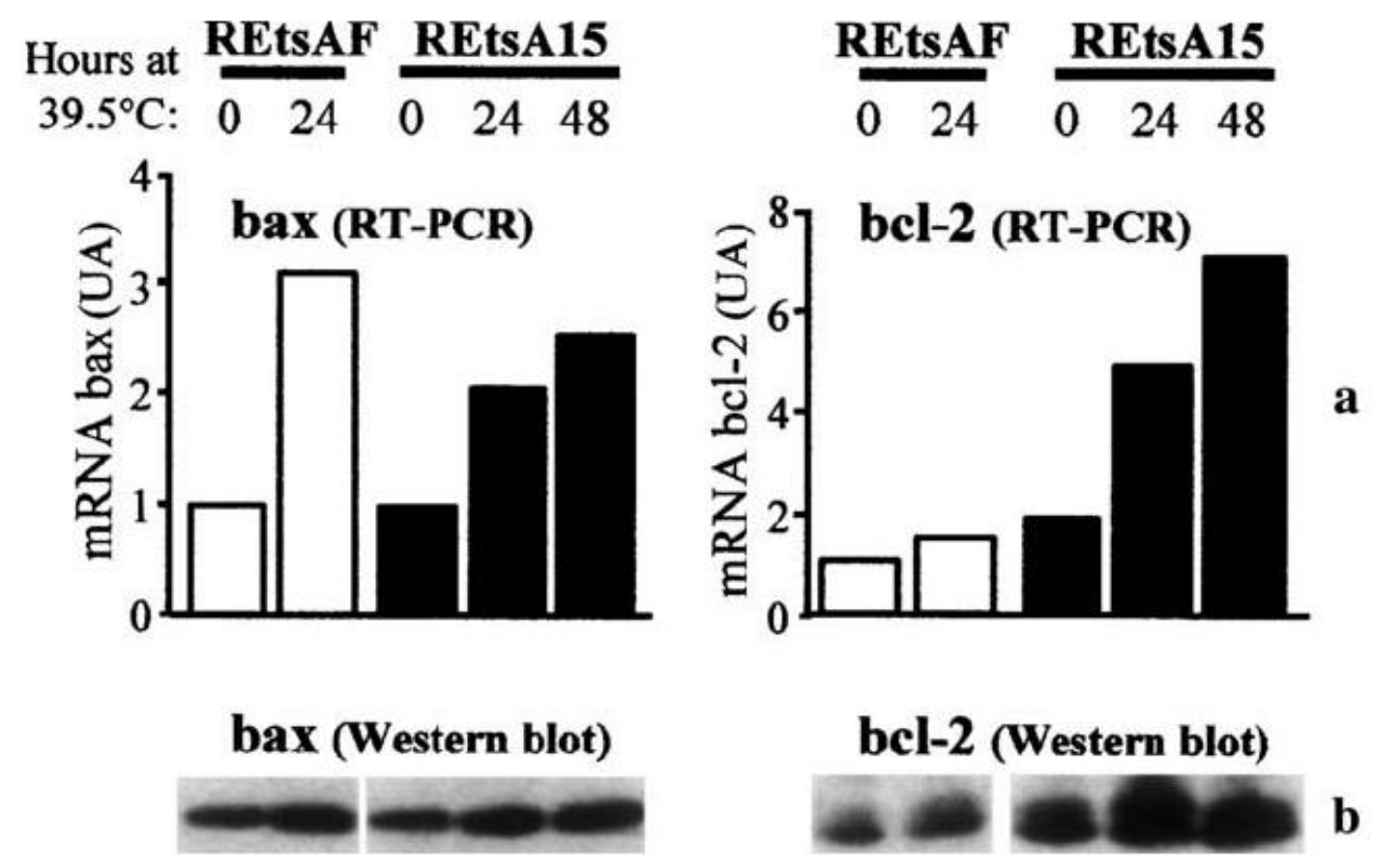

FIG. 2. Analysis of bax and $b c l-2$ expression in REtsAF and REtsA15 cells. RT-PCR and Western-blot analysis were performed to study expression of the bax and bcl-2 genes. RTPCR was used to characterise mRNA levels (a). For bax, similar basal levels were found in both cell lines whereas higher levels were observed for REtsAF cells at $39.5^{\circ} \mathrm{C}$. For $b c l-2$, higher levels were observed for REtsA15 at $33^{\circ} \mathrm{C}$ and $39.5^{\circ} \mathrm{C}$. Western-blot analysis (b) reveal that the Bax protein equally accumulates in both cell lines at $39.5^{\circ} \mathrm{C}$ whereas the amount of Bcl-2 is always superior in REtsA15 cells.

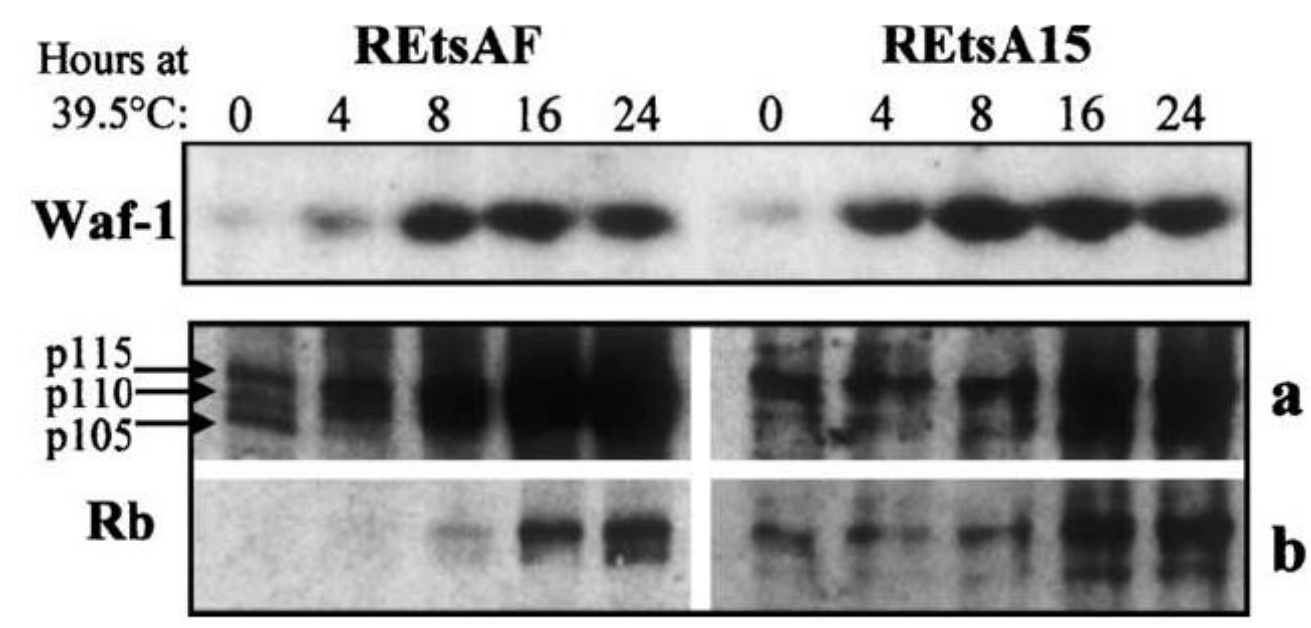

FIG. 3. Analysis of $p 21^{\text {Waf-1/Sdi-1/Cip } 1}$ expression and Rb phosphorylation. Western-blot analysis were performed to characterise the level of $\mathrm{p} 21^{\text {Waf- } 1 / \text { Sdi-1/Cip } 1}$ protein and $\mathrm{Rb}$ phosphorylation at $33^{\circ} \mathrm{C}$ and $39.5^{\circ} \mathrm{C}$. The $\mathrm{p} 21^{\text {Waf-1/Sdi-1/Cip } 1}$ protein accumulates in both cell lines at $39.5^{\circ} \mathrm{C}$. The analysis of $\mathrm{Rb}$ also shows that it accumulates in both cell lines at $39.5^{\circ} \mathrm{C}$. A long time exposure (a) allows to distinguish the hypophosphorylated (p105), phosphorylated (p110) and hyperphosphorylated (p115) forms of $\mathrm{Rb}$ in both cell lines at $33^{\circ} \mathrm{C}$. A short time exposure (b) shows that p105, the hypophosphorylated and active form of $\mathrm{Rb}$ disappears in REtsAF cells at $39.5^{\circ} \mathrm{C}$ whereas it accumulates in REtsA15 cells. 

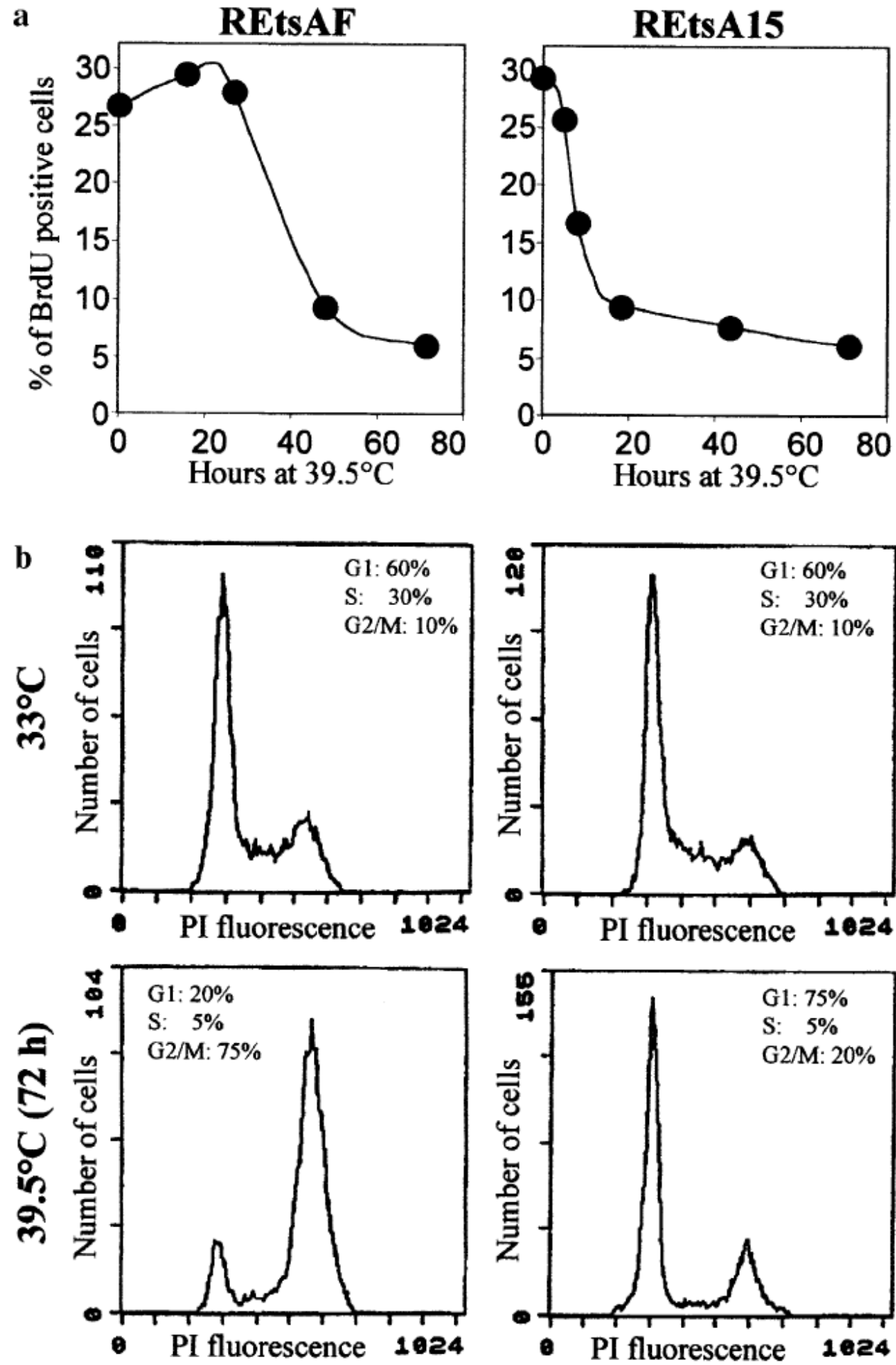

FIG. 4. Analysis of DNA synthesis and cell cycle regulation in REtsAF and REtsA15 cells. DNA synthesis was estimated by measuring BrdU incorporation at $33^{\circ} \mathrm{C}$ and $39.5^{\circ} \mathrm{C}$ by flow cytometry. The percentage of BrdU positive cells strongly decreases in both REtsA15 and REtsAF cells at $39.5^{\circ} \mathrm{C}$ but decreases more rapidly in REtsA15 cells than in REtsAF (a). The distribution of REtsAF and REtsA15 cells in the different phases of cell cycle, is identical at $33^{\circ} \mathrm{C}$ (b). At $39.5^{\circ} \mathrm{C}$, the proportion of REtsAF and REtsA15 cells in S phase decreases but REtsAF cells accumulate in G2/M phases whereas REtsA15 cells essentially accumulate in G1 phase. 

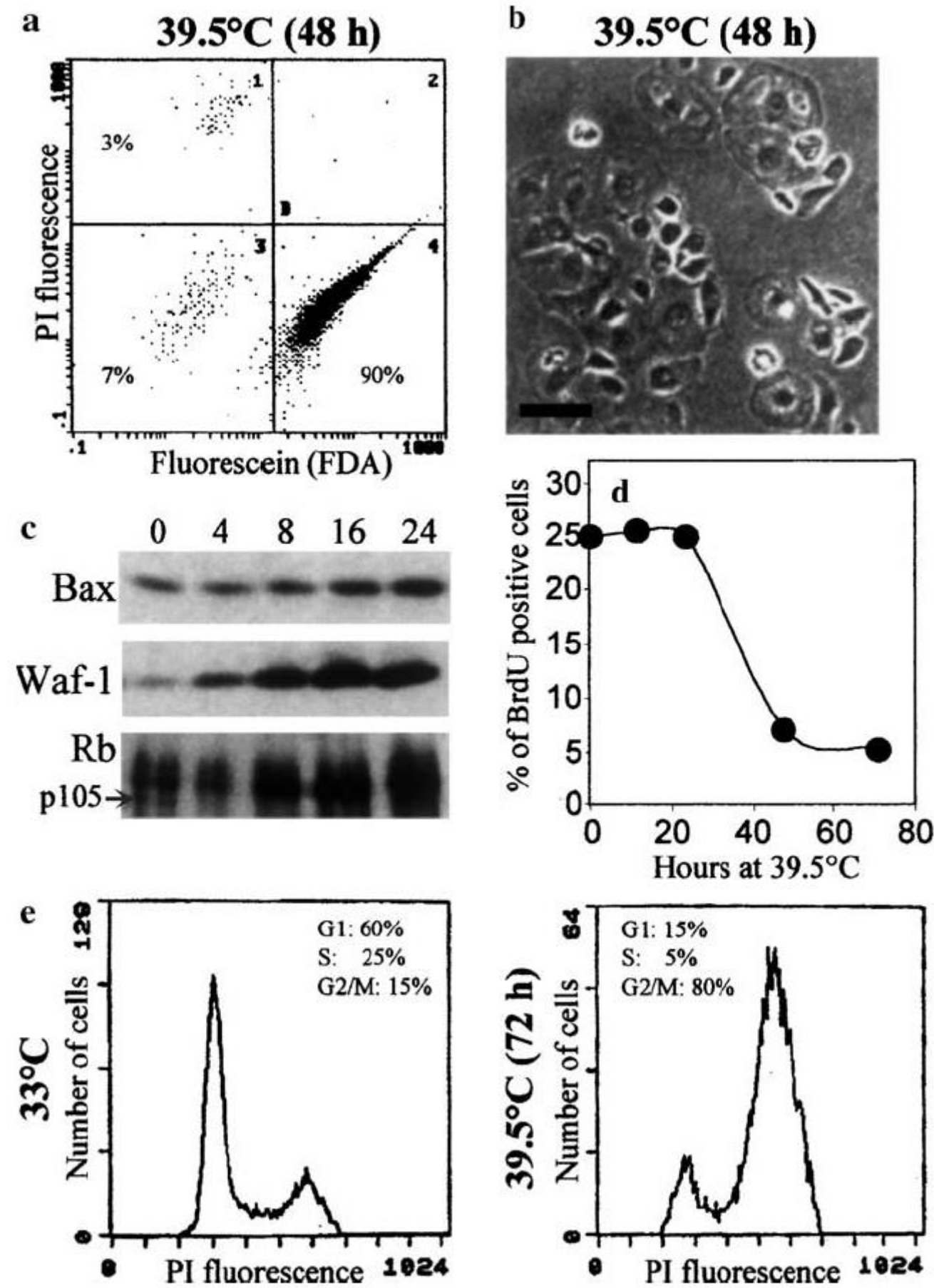

FIG.

5. Characterisation of the REtsAF-Bcl-2 phenotype at $39.5^{\circ} \mathrm{C}$. Analysis of cell death (a) reveals that REtsAF-Bcl- 2 cells at $39.5^{\circ} \mathrm{C}$ are essentially surviving cells. A photograph of REtsAF-Bcl-2 cells at $39.5^{\circ} \mathrm{C}$ (b) shows a senescent-like morphology and a Western-blot analysis shows a small accumulation of Bax, a strong accumulation of $\mathrm{p} 21^{\text {Waf-1/Sdi-1/Cip } 1}$ and an hyperphosphorylation of $\mathrm{Rb}$, similar to those observed in REtsAF cells at $39.5^{\circ} \mathrm{C}$. Finally, $b c l$ -

2 overexpression does not seem to modify significantly DNA synthesis (d) and cell cycle regulation (e) when compared to Figure 4. 